\title{
Resignations hit French science reforms
}

[PARIS] Plans by Claude Allègre, France's science minister, for sweeping reforms of the country's research system suffered a serious setback last week when the entire senior administration of his ministry's research department resigned en bloc.

The ministry has put a brave face on the unprecedented event. Daniel Nahon, director general of the department, explained that the seven directors who have offered their resignations want to leave for a variety of reasons, including simply wishing to return to their laboratories after a year of hard work at the ministry. (Nahon himself is also reported to have resigned, but he could not be contacted last week for confirmation.)

Pierre-Louis Curien, director of physics and engineering sciences at the ministry, says that one reason he resigned is to be able to return to research. But he adds that, although the ministry has identified important goals, its operational structures, new central research funds, and the structures established to coordinate the research agen- cies and universities, "have not yet converged to a setting that works satisfactorily" (see Nature 395, 422; 1998).

Curien says: "I hope very much that others will be able to carry out all this important work efficiently, and that, to begin with, a better picture of 'who does what' will be stabilized as soon as possible."

One explanation put forward for the mass resignation is confusion within the ministry over responsibilities. The resignations seem to have been partly prompted by the creation of a 'mission' for university research and doctoral studies within the department of research. This new entity is perceived by many in the department as duplicating much of the department's own brief, and solikely to provoke infighting.

The resignations are all the more embarrassing for the ministry because Allègre has made reform of his central administration the centrepiece of his overall reform strategy. The reorganization has streamlined the ministry from 19 departments to 11 , with money and power being concentrated in three: research, higher education and technology.

Jacques Fossay, a member of the main trade union representing scientists (SNCS), claims that the resignations mark a "disavowal" of Allègre's reform plans by those who would have had responsibility for implementing them. Fossay argues that it is difficult to believe that such drastic and symbolic action could be explained simply by dissatisfaction with organizational matters within the ministry.

Fossay says that those resigning cannot have failed to notice that the move comes at a critical time for Allègre. His reform plans face a revolt next week, when the National Committee for Scientific Research - an elected body of scientists that governs much of French research - will hold a plenary meeting to discuss the future of research, and to oppose Allègre's plans to reform the Centre National de la Recherche Scientifique, the country's basic research agency (see Nature 395, 729-730; 1998). DeclanButler

\section{Japanese industry defies recession to spend more on research}

[токуо] Despite Japan's severe economic situation, spending on industrial research and development increased by a record amount in the fiscal year 1997, according to figures released last week by Tokyo's Management and Coordination Agency.

The agency's annual report on $R \& D$ expenditure reveals that Japan's overall research spending grew by 4.4 per cent over the 1997 fiscal year, which ended in March. Total spending on $R \& D$ reached 3.12 per cent of the nation's gross national product - considerably higher than that of all other large industrialized nations (the United States, for example, spent 2.43 per cent of its gross national product on research in 1996).

The increased expenditure, however, only occurred in 'developmental costs', which account for 61.7 per cent of the overall $R \& D$ expenditure. In contrast, spending on basic research, which took up 13.8 per cent of total expenditure and is carried out primarily in universities and research institutes, has decreased from last year.

Although industry spent a modest 6.2 per cent on basic research, the figure has grown by 7.4 per cent from the previous fiscal year. But spending on basic research at universities and research institutes fell slightly from last year.

There was increased support for R\&D from all sectors, especially from industry, which faced considerable declines in both revenue and profits in 1997. Although such declines are continuing, many companies say their investment in R\&D is unlikely to suffer.

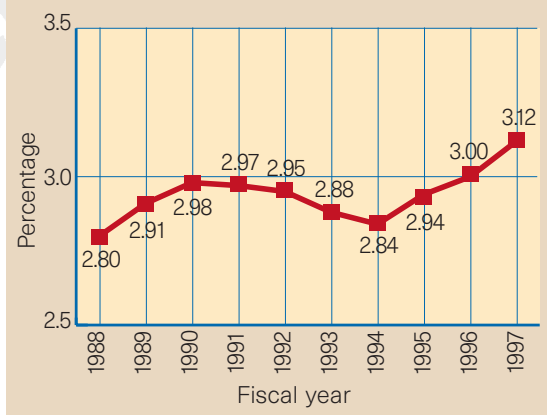

New heights: Japan is increasing the proportion of gross national product spent on $\mathrm{R} \& \mathrm{D}$.

The report is based on a survey of more than 15,000 companies, universities and research institutes across Japan. It estimates total R\&D expenditure at 15.7 trillion yen (US\$130 billion). Spending on industrial $R \& D$, excluding the software industry, grew by 6.1 per cent, while universities and research institutes showed modest increases of 0.8 and 1.5 per cent, respectively.

Overall private spending on research, which accounts for almost four-fifths of total $R \& D$ expenditure, increased by 4.9 per cent, with a marked increase in the electronics, telecommunications and transport sectors.

In contrast, however, public research spending grew by only 1.4 per cent, leading many to doubt whether Japan will reach its goal for the five-year plan for science and technology, launched in 1996, of doubling government spending on science by 2001 .
The discrepancy between the figure displayed in the survey and the projected increase of 11.9 per cent in government research funding budgeted for the 1997 fiscal year (see Nature 385,$104 ; 1997$ ) can be partly explained by generous supplementary budgets for the previous fiscal year.

Although supplementary budgets appeared to add considerably more to overall public research spending, the actual amount spent on research was minimal, and thus the target for the five-year plan is still likely to be out of reach.

A survey carried out by Nihon Keizai Shinbun, a financial daily newspaper, shows that major listed companies in Japan intend to spend even more on $R \& D$ in the current fiscal year. Sony plans to increase worldwide R\&D spending by $¥ 350$ billion, while the Matsushita Electric Industrial Company projects a 4.1 per cent rise to $¥ 500$ billion.

"Although profit and revenue declines are expected to continue into the current fiscal year, spending on $R \& D$ will be given priority, as we consider research to be the lifeline of the company," says Akira Kadota, a spokesman for Matsushita. Research in the key areas of digital television systems and large-capacity data-storage devices is likely to see a significant boost this year.

The pharmaceutical industry is also considering more $\mathrm{R} \& \mathrm{D}$ spending. "Whatever the economic situation, we cannot afford to reduce our investment in R\&D," says a spokesman for Eisai, one of Japan's largest pharmaceutical companies. Asako Saegusa 